AGRICULTURE AND BIOLOGY JOURNAL OF NORTH AMERICA

ISSN Print: 2151-7517, ISSN Online: 2151-7525, doi:10.5251/abjna.2013.4.1.84.90

(C) 2013, ScienceHu $\beta$, http://www.scihub.org/ABJNA

\title{
Determinants of raw milk quality under a smallholder production system in selected areas of Amhara and Oromia National Regional States, Ethiopia
}

\author{
G. Dehinenet ${ }^{1 \star}$, H. Mekonnen ${ }^{1}$, M. Ashenafi ${ }^{1}$, G. Emmanuelle ${ }^{2}$ \\ ${ }^{1}$ College of Veterinary Medicine and Agriculture, Addis Ababa University, P.O. Box 34, Debre \\ Zeit, Ethiopia \\ ${ }^{2}$ Livestock Officer FAO Sub Regional Office for Eastern Africa. \\ *Corresponding author: dehinenetfiker@gmail.com ; Mobile: 251-09-13-02-27-49 \\ ABSTRACT
}

\begin{abstract}
The determinants of raw milk quality were studied in 384 households from six districts of Amhara and Oromia National Regional States, Ethiopia. The analysis revealed that there is a significant difference $(P<0.01)$ in all physico-chemical milk quality parameters among the districts. The overall mean percentages of fat, solid non-fat (SNF) and protein obtained were 5.22, 8.44 and 3.12 in that order. Protein level had positive and negative significant $(P<0.01)$ correlations with lactose and freezing point respectively. Mean total bacterial count $(\mathrm{TBC} / \mathrm{ml})$, total coli form count $(\mathrm{TCC} / \mathrm{ml})$ and somatic cell count (SCC) were $1.1 \times 10^{8}, 3.0 \times 10^{4}$ and $5.5 \times 10^{5}$, respectively and there were significant differences between study sites. Milk handling and adulteration practices were the most likely causes for the observed difference in microbial quality of raw milk. Breed, parity number, feeding system, farming experience and distance from dairy technology dissemination centers had significant influence on fat and protein percentages. Practicing different dairy technology which is supported with a continuous training on how to manage the farm and integrated with a near proximity veterinary service; stronger milk quality control establishment and quality base payment should be practiced to discourage adulteration.
\end{abstract}

Key words: Milk composition, bacterial quality, determinant factors, smallholder, Ethiopia.

\section{INTRODUCTION}

Milk is a highly nutritious food, ideal for microbial growth. Fresh milk easily deteriorates to become unsuitable for processing and human consumption FAO (2001). According to Ramesh (2006), the major components of milk are water $(87.4 \%)$, milk solids $(12.60 \%)$, solids-not-fat $(9.0 \%)$, fat $(3.60 \%)$, protein $(3.40 \%)$, milk sugar or lactose $(4.90 \%)$ and ash or minerals $(0.70 \%)$. The constituents may vary with genetic (breed and individual cow and variability among cows within a breed) and environment (interval between milking, stage of lactation, age, feeding regime, disease and completeness of milking).

Milk is also an important vehicle for transmission of pathogenic microorganisms to human beings unless it is produced and handled under good hygienic conditions. Thus, hygienic production of milk has to get due attention in order to provide more and better quality milk for the general public.

It is a well-established fact that consumers want clean, wholesome and nutritious food that is produced and processed in a sound, sanitary manner and is free from pathogens. Hence, for fulfilling consumer's demand, quality milk production is necessary. Quality milk means, the milk which is free from pathogenic bacteria and harmful toxic substances, free from sediment and extraneous substances, of good flavor, with normal composition, adequate in keeping quality and low in bacterial counts Khan et al. (2008).

In Ethiopia, milk is produced in urban and rural areas mostly in non-organized way and usually supplied to the consumers in raw form. Along with population growth and technological intervention, policy reforms contributed to an estimate growth rate of milk production of $3 \%$ compared to $1.8 \%$ in the period of 1975-1992 Ahmed et al., (2004). However, the quality of milk remained poor. On the other hand, there is paucity of information regarding the factors that determine milk quality at household level. Understanding the factors affecting the milk quality is critical to success of development and implementation of policies and programs in dairy industry. The current study, therefore, aimed to fulfill 
this gap by evaluating the milk quality and identifying the factors that determine milk quality at household level.

\section{MATERIALS AND METHODS}

Description of study site: This study was carried out in Amhara and Oromia National Regional States of Ethiopia. The Amhara National Regional State (ANRS) is located in the north-western part of the country which is found between 90-130 45"North Latitude and 350-400 30"East longitude. The total area of the Region is approximately $170,752 \mathrm{Km}^{2}$ whereas the Oromia National Regional State (ONRS) lies in the central part of the country with larger protrusions towards the south and west directions. It has an area of $353,690 \mathrm{~km}^{2}$ OPEDB (2000).

Sampling procedure and sample size: Purposive and random multistage stratified sampling procedures were used to select farm households. The study Regions were selected purposively based on the intensity of dairy technology adoption, which was delivered by Smallholder Dairy Development Program (SDDP), milk production potential and number of crossbred cows distributed. One zone from Amhara National Regional State (East Gojjam Zone) and two zones from Oromia National Regional State (North Showa and East Showa zones) were selected based on the dairy potential of the zones. Cooperative areas (two from each zone) were selected randomly. Totally, six cooperative areas namely Shemeshengo and Yetenora from ANRS and Godino, Babogaya, Debretsigie and Torbenashie from ONRS were selected. Finally, lists (census) of farm households of the selected areas were obtained from district Agriculture and Rural Development Offices. The farm households were categorized into dairy technology adopters and non-adopters and the ones having at least one lactating cow at the time of survey constituted sampling units.

Sample size was determined at $95 \%$ confidence interval and margin for random error of $5 \%$ by using a mathematical model as described by Fox et al. (2007).

$\mathrm{N}=\mathrm{P}(100 \%-\mathrm{P}) /(\mathrm{SE})^{2} ; \mathrm{SE}=\mathrm{MRE} / 1.96$

Where;

$\mathbf{N}$ = Sample size; $\mathbf{P}=$ Proportion of dairy technology adopter smallholder farmers; SE = Standard error; MRE = Margin for random error (5\%) and 1.96 is tabular value for $95 \%$ confidence interval.

Accordingly the calculated sample size was 384 . Systematic random sampling method was used to identify study participants and the number of households selected from each cooperative area was proportionate to the size of the farm households of the area.

Data collection: Data were collected by way of questionnaire survey and physico-chemical and bacteriological analysis of milk samples. The questionnaire was administered through personal interviews by trained enumerators, using a pre-tested and semi-structured questionnaire format. The questionnaire was focusing on household socioeconomic characteristics of farmers that include farmer's age, gender, marital status, educational status, land size, farming experience and family size, and husbandry practices like breeding and feeding practices.

Collection of milk samples: Milk samples were collected from morning bulk tank milk at farm level, before delivery to dairy cooperatives. Approximately 25 - $45 \mathrm{ml}$ milk was collected from each sampling unit, as per the procedure described by O'Connor (1995), in to sterile containers and after thorough mixing. A total of 384 samples were taken for physico-chemical analysis that was done at field level. Of the 384 milk samples 80 were randomly taken for bacteriological analysis and somatic cell count. The samples were transported on ice box to the Ethiopian Meat and Dairy Technology Institute's microbiology laboratory, where they were analyzed on the same day.

Examination of milk samples: Physico-chemical characteristics of the milk samples were determined using milk analyzer (LACTOSCAN S, LSS001, Bulgaria) at field level to determine milk constituents (fat, solid non fat, protein, lactose and salt) and physical characteristics (density, temperature, and freezing point).

Total bacteria count (TBC), total coliform count (TCC), and somatic cell count (SCC) were conducted following standard procedures Francesconi (2006).

For Bacterial Count, using a sterile-standardized loop, $1 \mathrm{ml}$ of milk sample was diluted with "Peptone Water" progressively to the levels $1 / 10,1 / 100$, $1 / 1000,1 / 10000,1 / 100000,1 / 1000000$, and $1 / 10000000$. Dilution levels, $1 / 100$ and $1 / 1000$ were cultured in duplicate at first. Each culture was constituted of $1 \mathrm{ml}$ of the diluted solution poured on a petridish, on which $12-15 \mathrm{ml}$ of "Standard Plate Agar" was added. When the solution in the petridish solidifies, it was put in to incubator at $37^{\circ} \mathrm{C}$ for 48 hours, after which the number of bacterial colonies grown was counted. When the colonies found to be too many, compromising the accuracy of counting, 
the same procedure was repeated using higher dilution levels.

The Coli form Count is a test that estimates the number of bacteria that originate from manure or a contaminated environment. Milk samples were plated on Violet Red Bile agar and incubated at $32^{\circ} \mathrm{C}$ for 48 hours, after which typical coli form colonies were counted.

The corresponding TCC and TBC were computed from duplicate plates containing between 25-250 colonies. Plates containing less than 25 colonies were taken as less than 25 estimated counts and plates containing greater than 250 colonies for all dilutions were recorded as too numerous to count (TNTC). For analysis purpose only counts in the normal (25-250) were taken directly. When all plates counted less than 25, the nearest count to 25 was taken and when all plates counted greater than 250 colonies for all dilutions, the nearest colony count to 250 was taken APHA (1992). To avoid a fictitious impression of precision and accuracy when computing the counts, only the first two significant digits were reported by rounding up or down to the next number. The following formula was used to calculate the counts.

$$
N=\frac{\sum C}{\left[\left(1 \mathrm{xn}_{1}\right)+\left(0.1 \times \mathrm{n}_{2}\right)\right] d}
$$

Where:

$\mathrm{N}=$ Number of colonies per $\mathrm{ml}$ or $\mathrm{g}$ of product; $\Sigma \mathrm{C}=$ Sum of all colonies on all plates counted; $\mathrm{n}_{1}=$ Number of plates in first dilution counted; $\mathrm{n}_{2}=$ Number of plates in second dilution counted $\mathrm{d}=$ Dilution from which the first counts were obtained

Somatic Cells Count was conducted following the procedure described by Francesconi (2006). About $0.01 \mathrm{ml}$ milk was spread homogeneously over a microscope slide by using a sterile-standardized loop. Once the milk layer has dried up, Ethanol $96 \%$ was added. After waiting for 15 minutes Tolouidin Blue $0.2 \%$ was added. The slide was then kept on open air for 5 minutes, after which it was washed with tap running water, dried and then observed by using a microscope at 100 times magnification. Somatic cells in twenty different fields $(A)$ were counted. Given the dimension of the microscope zoom $(F$; in this case $=$ $0.0346)$, the somatic cells count $(N)$ is equal to: $N=A$ $\mathrm{x} 10000$ / F.

Statistical analyses: Data were analyzed by SPSS (Statistical Package for Social Science, version 17.00) computer program. Analysis of variance (ANOVA) and Post Hoc (Duncan) were used to determine the statistical difference of milk quality parameters among the different study areas. Multicollinearity and homogeneity of the variables were tested using collinearity statistics (tolerance and VIF-variance inflation factors). Pearson correlation and multiple regressions were used to analyze the association between milk quality parameters and the effect of different independent variables on the milk quality, respectively.

The empirical model used was:

$$
\begin{gathered}
Y_{i}=\beta_{0}+\beta_{1} X_{1 i}+\beta_{2} X_{2 i}+\beta_{3} X_{3 i}+\beta_{4} X_{4 i}+\beta_{5} X_{5 i}+\beta_{6} X_{6 i}+ \\
\beta_{7} X_{7 i}+\beta_{8} X_{8 i}+\varepsilon_{i} .
\end{gathered}
$$

Where, $Y_{i}$ is the dependent variable which is a milk quality parameter, $X_{1}=$ family size, $X_{2}=$ farm experience, $X_{3}=$ parity number of cow, $X_{4}=$ distance from dairy technology dissemination center, $X_{5}=$ adulteration by water addition, $\mathrm{X}_{6}=$ educational status of households, $X_{7}=$ feeding system, $X_{8}=$ breed, $\beta_{0}=$ constant(intercept), $\beta_{1}, \beta_{2, \ldots . ., \beta_{8}}=$ are coefficients $\varepsilon_{\mathrm{i}}=$ the error term.

\section{RESULTS}

Table 1 illustrates physico-chemical properties of milk samples from different study areas. Milk samples from Yetenora study site tested highest for fat percentage $(5.97 \pm 2.36)$ while that of Babogaya was lowest $(3.55 \pm 1.15)$.

There was a significant difference $(P<0.01)$ in fat \% among the study areas and the overall mean value of the fat $(5.22 \%)$ in the study area is higher than Ethiopian standard (ES) value (3.50\%), ES (2009). There was also a difference in solid nonfat (SNF) values between the study areas $(\mathrm{P}<0.01)$ with the highest percentage $(8.88 \pm 0.83)$ in milk samples from the Shemeshengo study area. The table also shows that there is a significant difference $(P<0.05)$ in density percentage between study areas. Babogaya and Shemeshengo samples were significantly different $(\mathrm{P}<0.05)$ from those of Debretsegie, Torbenashe and Godino. The mean value of protein percentage was $3.12 \pm 0.32$ and Godino, Babogaya and Shemeshengo were significantly different $(\mathrm{P}<0.01)$ from Debretsegie, Torbenashe and Yetenora. The overall mean value of protein $(3.12 \%)$ in the study area is slightly lower than Ethiopian standard value (3.20\%), ES (2009). Addition of water on the milk (adulteration) was also highest in Debretsegie milk samples and significantly different $(P<0.01)$ from those of Shemeshengo and Yetenora. The freezing point of the milk was lowest in Shemeshengo $\left(-0.587^{\circ} \mathrm{C}\right)$ and highest in Debretsegie $\left(-0.531^{0} \mathrm{C}\right)$; with a significant difference $(\mathrm{P}<0.01)$. 
Agric. Biol. J. N. Am., 2013, 4(1): 84-90

Table 1: Phyisco-chemical quality of cow raw milk in the study area

\begin{tabular}{|c|c|c|c|c|c|c|c|}
\hline \multirow{2}{*}{$\begin{array}{l}\text { Milk quality } \\
\text { parameters }\end{array}$} & \multicolumn{7}{|c|}{ Mean values of milk physico-chemical quality parameters across the study districts } \\
\hline & $\begin{array}{c}\mathrm{A}_{1} \\
(\mathrm{~N}=75)\end{array}$ & $\begin{array}{c}\mathrm{A}_{2} \\
(\mathrm{~N}=60)\end{array}$ & $\begin{array}{c}A_{3} \\
(N=30)\end{array}$ & $\begin{array}{c}\mathrm{A}_{4} \\
(\mathrm{~N}=53)\end{array}$ & $\begin{array}{c}\mathrm{A}_{5} \\
(\mathrm{~N}=67)\end{array}$ & $\begin{array}{c}A_{6} \\
(N=99)\end{array}$ & $\begin{array}{l}\text { Over all mean } \\
\quad(\mathrm{N}=384)\end{array}$ \\
\hline Fat (\%) & $4.72(2.13)^{\mathrm{b}}$ & $5.57(1.87)^{\mathrm{C}}$ & $4.74(1.94)^{b}$ & $3.55(1.15)^{\mathrm{a}}$ & $5.89(2.03)^{\mathrm{C}}$ & $5.97(2.36)^{\mathrm{C}}$ & $5.22(2.17)^{m}$ \\
\hline SNF (\%) & $8.16(0.61)^{\mathrm{a}}$ & $8.27(0.60)^{\mathrm{ab}}$ & $8.72(0.78)^{\mathrm{cd}}$ & $8.14(0.41)^{\mathrm{a}}$ & $8.88(0.83)^{\mathrm{d}}$ & $8.52(0.71)^{\mathrm{bc}}$ & $8.44(0.72)$ \\
\hline Density (\%) & $28.04(2.82)^{\mathrm{a}}$ & $27.78(3.22)^{\mathrm{a}}$ & $28.07(4.05)^{\mathrm{a}}$ & $29.55(1.78)^{b}$ & $29.53(4.31)^{b}$ & $28.91(3.09)^{\mathrm{ab}}$ & $28.70(3.31)$ \\
\hline Protein (\%) & $2.98(0.22)^{\mathrm{a}}$ & $3.02(0.22)^{a}$ & $3.30(0.28)^{b}$ & $3.36(0.13)^{b}$ & $3.25(0.36)^{b}$ & $3.09(0.37)^{\mathrm{a}}$ & $3.12(0.32)$ \\
\hline Adulteration (\%) & $2.08(0.48)^{D}$ & $1.67(0.53)^{\mathrm{ab}}$ & $1.57(0.69)^{\mathrm{ab}}$ & $1.13(0.37)^{\mathrm{ab}}$ & $0.68(0.31)^{a}$ & $0.47(0.24)^{a}$ & $1.19(0.17)$ \\
\hline $\mathrm{FP}\left({ }^{0} \mathrm{C}\right)$ & $-0.531(.042)^{\mathrm{C}}$ & $-0.542(.046)^{\mathrm{C}}$ & $-0.573(.039)^{\mathrm{ab}}$ & $-0.562(.026)^{D}$ & $-0.587(.059)^{\mathrm{a}}$ & $-0.565(.038)^{\mathrm{D}}$ & $-0.559(.047)$ \\
\hline
\end{tabular}

$A_{1}=$ Debretsegie; $A_{2}=$ Torbenashe; $A_{3}=$ Godino; $A_{4}=$ Babogaya; $A_{5}=$ Shemeshengo; $A_{6}=$ Yetenora

Numbers in bracket are standard deviation; values in the row with different letters have significant difference.

$\mathrm{SNF}=$ solid Non-Fat; FP= Freezing Point; ${ }^{* * *}=$ significant at $(\mathrm{P}<0.01)$ and ${ }^{* *}=$ significant at $(\mathrm{P}<0.05)$

\section{Table 2: Microbial quality of cow raw milk in the study areas}

\begin{tabular}{|c|c|c|c|c|c|c|c|}
\hline \multirow{3}{*}{$\begin{array}{l}\text { Sources of } \\
\text { Samples }\end{array}$} & \multirow[t]{3}{*}{ No of Samples Tested } & \multicolumn{6}{|c|}{ Mean values of milk bacteriological quality of raw milk } \\
\hline & & \multicolumn{2}{|c|}{$\mathrm{TBC} / \mathrm{ml}$} & \multicolumn{2}{|c|}{$\mathrm{TCC} / \mathrm{ml}$} & \multicolumn{2}{|c|}{$\mathrm{SCC} / \mathrm{ml}$} \\
\hline & & $\mathrm{Cfm} / \mathrm{ml}$ & $\log 10$ & $\mathrm{Cfm} / \mathrm{ml}$ & Log10 & $\begin{array}{l}\text { Somatic } \\
\text { cells } / \mathrm{ml}\end{array}$ & $\log 10$ \\
\hline$A_{1}$ & 10 & $4.3 \times 10^{\prime}$ & $7.6(0.72)^{\mathrm{ab}}$ & $1.0 \times 10^{4}$ & $4(0.30)^{\mathrm{ab}}$ & $1.6 \times 10^{6}$ & $6.2(0.86)^{\mathrm{C}}$ \\
\hline $\mathrm{A}_{2}$ & 10 & $1.6 \times 10^{8}$ & $8.2(0.81)^{\mathrm{bc}}$ & $1.2 \times 10^{4}$ & $4.1(0.86)^{\mathrm{a}}$ & $3.8 \times 10^{5}$ & $5.8(0.70)^{\mathrm{C}}$ \\
\hline $\mathrm{A}_{3}$ & 10 & $5.1 \times 10^{\prime}$ & $7.7(0.95)^{\mathrm{a}}$ & $4.1 \times 10^{4}$ & $4.6(0.75)^{\mathrm{bc}}$ & $1.5 \times 10^{5}$ & $5.2(0.83)^{\mathrm{ab}}$ \\
\hline $\mathrm{A}_{4}$ & 10 & $1.7 \times 10^{8}$ & $8.2(0.62)^{\mathrm{C}}$ & $5.8 \times 10^{4}$ & $4.8(0.60)^{\mathrm{C}}$ & $2.5 \times 10^{5}$ & $5.4(2.56)^{\mathrm{a}}$ \\
\hline $\mathrm{A}_{5}$ & 10 & $7.5 \times 10^{\prime}$ & $7.9(1.10)^{\mathrm{ab}}$ & $1.6 \times 10^{4}$ & $4.2(0.68)^{\mathrm{ab}}$ & $4.0 \times 10^{5}$ & $5.6(2.25)^{\mathrm{ab}}$ \\
\hline$A_{6}$ & 10 & $1.4 \times 10^{8}$ & $8.1(0.60)^{b c}$ & $4.5 \times 10^{4}$ & $4.7(0.30)^{\mathrm{C}}$ & $5.1 \times 10^{5}$ & $5.7(0.68)^{a b}$ \\
\hline Total & 60 & $1.1 \times 10^{8}$ & $8.0(0.89)$ & $3.0 \times 10^{4}$ & $4.5(0.71)$ & $5.5 \times 10^{5}$ & $45.7(1.60)$ \\
\hline \multicolumn{2}{|c|}{ Level of overall significance } & & 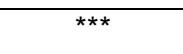 & & $* \star \star$ & & NS \\
\hline
\end{tabular}

$\mathrm{A}_{1}=$ Debretsegie; $\mathrm{A}_{2}=$ Torbenashe; $\mathrm{A}_{3}=$ Godino; $\mathrm{A}_{4}=$ Babogaya; $\mathrm{A}_{5}=$ Shemeshengo $\mathrm{A}_{6}=$ Yetenora; TBC= Total Bacteria Count; TCC= Total Coli forms Count; $\mathrm{SCC}=$ Somatic Cell count;

${ }^{* *}=$ significant at $(P<0.01)$ and ${ }^{* *}=$ significant at $(P<0.05)$; values in the same column with different letters have significant difference. 
Table 2 reveals the microbial quality of the milk samples. The mean value of total bacterial count per milliliter $(\mathrm{TBC} / \mathrm{ml})$ ranged from $4.3 \times 10^{7}$ to $1.7 \times 10^{8}$ with a significant difference $(P<0.05)$ among the study areas. This value is highly greater than the minimum quality standard value of the country $(2 \mathrm{x}$ $10^{6}$ ), ES (2009). The overall bacterial count showed even higher difference $(P<0.01)$. Total coliform count also showed comparable variability between the study areas $(\mathrm{P}<0.01)$. The overall mean somatic cell count $5.5 \times 10^{5}(\log 10(45.7))$ didn't show significant difference $(P>0.05)$. However, somatic cell counts of Debretsegie and Torbenashe study areas significantly differed $(\mathrm{P}<0.05)$ from those of the other study areas.
Table 3 shows correlation coefficients between the different milk quality parameters. Density of raw milk was negatively and significantly correlated with fat content $(p<0.01)$ and positively and significantly correlated with solid non-fat $(p<0.01)$. Protein content was negatively and significantly correlated with fat content $(p<0.01)$. In addition, protein was correlated positively and significantly with both SNF and density $(p<0.01)$ whereas lactose was correlated positively and significantly with SNF, density and protein $(p<0.01)$. On the other hand adulteration (water addition) and freezing point were negatively and significantly correlated with SNF $(p<0.01)$, density $(p<0.01)$, protein $(p<0.01)$ and lactose $(p<0.01)$ but there was positive and significant correlation between adulteration and freezing point $(P<0.01)$.

Table 3: Correlation coefficients between different milk quality parameters in the study areas; $N=384$

\begin{tabular}{|c|c|c|c|c|c|c|c|}
\hline Variable & Fat & SNF & Density & Protein & Lactose & Water add. & $\mathrm{FP}$ \\
\hline Fat & 1 & -.072 & $-.6033^{(*)}$ & $-.188\left(^{(* *)}\right.$ & -.099 & $-.129\left({ }^{*}\right)$ & $-.116\left(^{*}\right)$ \\
\hline SNF & & 1 & $.663\left({ }^{* *}\right)$ & $.866\left({ }^{* *}\right)$ & $.877\left(^{* *}\right)$ & $-.142\left({ }^{* *}\right)$ & $-.567\left(^{* *}\right)$ \\
\hline Density & & & 1 & $.582\left({ }^{* *}\right)$ & $.753\left({ }^{* *}\right)$ & -.049 & $\left.-.309^{(* *}\right)$ \\
\hline Protein & & & & 1 & $.746\left(^{* \star}\right)$ & $-.109\left(^{*}\right)$ & $\left.-.500^{(* *}\right)$ \\
\hline Lactose & & & & & 1 & $-.179\left({ }^{* *}\right)$ & $-.672\left(^{* *}\right)$ \\
\hline Water & & & & & & 1 & $.590\left({ }^{* *}\right)$ \\
\hline FP & & & & & & & 1 \\
\hline
\end{tabular}

** Correlation is significant at the 0.01 level (2-tailed); ${ }^{*}$ Correlation is significant at the 0.05 level (2-tailed);

$\mathrm{SNF}=$ Solid Non Fat; FP= Freezing Point.

The results of the regression analysis are presented in Table 4. The coefficients of determination (adjusted R-squares) indicate the variation of the overall raw milk quality in the study area by using 8 variables in the model. Hence, the results in Table 4 show the important factors influencing raw milk quality in the study area. All the coefficients have the expected signs. Only those coefficients associated with statistically significant variables at the 10-percent level or better are presented.

The effect of breed (dummy variable denoted by 1 for local breed and 0 for crossbred) was found to have positive significant $(P<0.01)$ effect on fat and protein percentages and on total coli form count, but negative significant $(P<0.01)$ effect on freezing point. Milk from local breed cows has $0.74,0.10$ and 0.57 percent higher fat percentage, protein percentage and total coli form count, respectively, than crossbred cows.

The feeding system (dummy variable denoted by 1 for stall feeding and 0 for grazing) had also significant negative $(P<0.01)$ influence on protein percentage and positive influence on freezing point of raw milk. Feeding system had also significant $(P<0.1)$ association with somatic cell count of raw milk. Milk from farms which practice stall feeding had an increased somatic cell count and freezing point by 0.87 and 0.007 percents than farms practicing grazing system. However, in stall feeding farms, a 0.1 lower protein percentage was recorded.

Education level (dummy variable denoted by 1 for formal education and 0 for informal education) showed a negative significant $(P<0.1)$ effect on somatic cell count. The result reveled that formal education can reduce somatic cell count by 0.74 percent than milk from household heads with informal education.

Addition of water on raw milk had a positive significant effect on freezing point $(P<0.01)$ and total coliform count $(P<0.1)$, but negative significant $(P<0.05)$ effect on protein percentage. By taking other factors constant, increase of a unit of water addition in raw milk caused increases in freezing point and total coliform count by 
0.005 and 0.03 rates, respectively, and protein percentage decreases by 0.009 rate.

Distance from dairy technology dissemination center had positive significant $(\mathrm{P}<0.05)$ effect on protein percentage and negative significant $(P<0.01)$ effect on freezing point. Increasing a unit distance caused protein to increase by 0.008 rate and freezing point to decrease by 0.001 . The coefficients of parity had negative and positive significant $(P<0.01)$ effects on fat and protein percentages, respectively.

Table 4: Multiple regression analysis of effects of independent variables on raw milk quality

\begin{tabular}{|c|c|c|c|c|c|}
\hline \multirow{3}{*}{$\begin{array}{l}\text { Independent } \\
\text { variables }\end{array}$} & \multicolumn{5}{|c|}{ Dependent variables } \\
\hline & Fat $\%$ & Protein\% & FP & TCClog10 & SCClog10 \\
\hline & $\beta$ & $\mathrm{B}$ & $\beta$ & $\mathrm{B}$ & $\beta$ \\
\hline Intercept & $7.61(0.42)^{\mathrm{a}}$ & $3.05(.06)$ & $-0.56(0.01)$ & $3.20(0.46)$ & $6.13(1.00)$ \\
\hline FS & $-0.07(0.04)^{\star}$ & $.006(000)$ & $.001(.001)$ & $0.005(.04)$ & $-0.09(.08)$ \\
\hline FE & $0.016(0.01)^{\star}$ & $.001(.001)$ & $000(000)$ & $0.01(0.01)$ & $-0.03(.02)$ \\
\hline PNC & $-1.15(0.08)^{\star \star \star}$ & $0.04(0.01)^{\star \star \star}$ & $.002(.002)$ & $.11(0.09)$ & $-0.25(0.19)$ \\
\hline DDTDC & $-0.002(0.023)$ & $.008(.004)^{\star \star}$ & $-0.001(0.0)^{\star \star \star}$ & $.003(0.02)$ & $.005(.04)$ \\
\hline WaAd & $-0.02(0.02)$ & $-.009(.004)^{\star \star}$ & $.005(0.001)^{* * *}$ & $.03(0.02)^{*}$ & $.005(0.03)$ \\
\hline Education $^{\mathrm{b}}$ & $0.01(0.18)$ & $.01(.028)$ & $.005(0.004)$ & $.12(0.21)$ & $-.74(.44)^{*}$ \\
\hline FeSys $^{\mathrm{b}}$ & $-0.2(0.20)$ & $-0.10(0.03)^{\star \star \star}$ & $.007(.004)^{\star *}$ & $.25(0.23)$ & $.87(.48)^{\star}$ \\
\hline Breed $^{b}$ & $0.74(0.22)^{\star \star \star}$ & $0.10(0.03)^{\star \star \star}$ & $-.01(.004)^{\star \star \star}$ & $.57(.24)^{\star \star}$ & $-.73(0.51)$ \\
\hline$R$-square & 0.428 & 0.142 & 0.322 & 0.219 & 0.317 \\
\hline & $\begin{array}{c}F(9,374)= \\
28.79, P=000\end{array}$ & $\begin{array}{c}F(9,374)=6.25, P \\
=000\end{array}$ & $\begin{array}{c}F(9,374)=17.81, \\
P=000\end{array}$ & $\begin{array}{c}F(9,50)=1.41, P= \\
0.204\end{array}$ & $\begin{array}{c}F(9,50)=2.29, \\
P=.0 .027\end{array}$ \\
\hline
\end{tabular}

${ }^{* * *}$ : denotes $\mathrm{P}<0.01,{ }^{* *}$ : denotes $\mathrm{P}<0.05{ }^{*}$ : denotes $\mathrm{P}<0.1^{\mathrm{a}}=$ number in the bracket is a standard error,

$\stackrel{b}{=}$ shows the dummy explanatory variables ( Education $(0=$ informal, $1=$ formal $)$; FeSys $(0=$ grazing, $1=$ stall feeding; Breed $(0=\mathrm{crossbred}$, $1=$ local), $\beta=$ unsaturated regression coefficient, FP = freezing point, $\mathrm{TCC}=$ Total Coli forms Count; $\mathrm{SCC}=\mathrm{Somatic}$ Cell count, FS = family size, $\mathrm{FE}=$ farming experience, $\mathrm{PNC}=$ parity number of cow, DDTDC $=$ distance from dairy technology dissemination center, $\mathrm{WaAd}=$ water addition, FeSys $=$ feeding system

\section{DISCUSSION}

The overall mean fat content of $5.22 \%$ in the study areas was higher than what was reported by Francesconi (2006) for cooperative smallholders in Ethiopia (4\% fat). Results from analysis of variance

(ANOVA) showed that milk samples from remote districts (Yetenora and shemeshengo in Amhara National Regional State) had significantly $(P<0.01)$ higher fat content than those sites (Babogaya and Tebretsige) which closer to the capital city. This is probably due to less utilization of crossbred cows in the remote areas due to limited access to raw milk market. Local breeds are known to test higher fat percentage than cross or pure exotic breeds (Mesfin and Getachew, 2007). The protein content of $3.12 \%$ observed in the present study is, however, comparable to the report by Francesconi (2006).

The TBC as well as TCC results showed significant differences $(p<0.01)$ between the study areas, reflecting variability in bacterial contamination of milk in different locations. Milk samples from Debretsegie had least counts both for TBC and TCC while milk samples from Babogaya and Torbenashe sites had highest values, respectively for TBC and TCC. On the other hand Debretsegie milk samples tested highest for SCC What can be speculated is that at Debretsegie study site, dairy cows were managed poorly as can be seen from high SCC indicating mastitis problem, but milk handling practices was relatively good; least contamination was observed. The presence of bacteria may be due to external factors because TBC increased with TCC. The overall mean total bacteria count (TBC) in the present study $\left(8.0 \log _{10} \mathrm{cfu} / \mathrm{ml}\right)$ is higher than what was reported by Asaminew and Eyassu (2010) (7.58 $\log _{10}$ ) but lower than the report of Francesconi, (2006) (8.78 $\log _{10}$ $\mathrm{cfu} / \mathrm{ml})$. The overall mean coliform count (4.5 $\log _{10}$ $\mathrm{cfu} / \mathrm{ml}$ ) was, however, similar with the results of the same authors (4.49 $\left.\log _{10} \mathrm{cfu} / \mathrm{ml}\right)$.

Results from the association analysis revealed that there was a significant negative correlation between both water addition (adulteration) and freezing point and all other milk quality parameters. Adulteration had positive significant $(P<0.01)$ association with freezing point. This result in line with what Kurwijila (2006) revealed that water adulteration lowers the specific gravity and increases the freezing point of milk. Both physico-chemical and microbial quality of the milk could be affected by different explanatory variables. Breed has a positive significant $(P<0.01)$ effect on fat and protein percentage of fresh cow milk. Local breed cows fresh milk has greater fat and protein content with 0.74 and $0.1 \%$ respectively, higher than crossbred cow but it has $0.01 \%$ lower freezing point. This result is in agreement with the finding of Fikirneh et al.(2012), which stated that local Arsi zebu cows (5.87 $\pm 0.25 \%$ ) were observed to have high fat percent than crossbred 
cows $(5.02 \pm 0.25 \%)$. Total coliform count was also found higher $(0.57 \%)$ in local breed. The later, however, had lower somatic cell count $(0.73 \%)$. Protein content of the milk is increased by $0.04 \%$ when the parity number of the cow increased by one but the fat content was decreased by $1.15 \%$.

Stall fed herds produced milk with $0.1 \%$ less protein content and $0.89 \%$ increased somatic cell count compared to free grazing animals. The increased risk of mastitis (higher somatic cell count) in stall fed cows was also reported by FRELICH and ŠLACHTA (2011): The decreased protein percentage of milk in grazing animals might, however, be due to poor nutritional quality of natural pastures. Education was also significantly $(P<0.1)$ associated with somatic cell count; the latter being less in milk samples from households with formal education. Education, by improving access to information, might have a role to play in influencing udder health.

Addition of water increased freezing point and total coli form count with the rate of $0.005 \%$ and $0.03 \%$ respectively. Therefore, milk adulteration with water might, at least partly, explain the difference in milk bacterial count between the different study areas.

\section{CONCLUSIONS}

Regardless of having a significance difference among the study sites, both total bacterial count (TBC), total coli form count (TCC) and somatic cell count (SCC) test results illustrated that the quality of milk in the study areas was poor as compared with the established standard of raw milk quality in Ethiopia. Addition of water was commonly practiced in areas that are near to the capital city or have access to fresh milk market. It strongly affected the quality of fresh milk. Despite the fact that high milk production was attained by using crossbred animals and practicing stall feeding, the milk quality showed deterioration. Therefore, it is recommended that introducing different dairy technologies should be supported with a continuous training on how to manage a dairy farm. Stronger milk quality control and quality base payment could help a lot to discourage adulteration.

\section{ACKNOWLEDGEMENT}

We acknowledge ILRI-DAAD and FAO for their support and smallholder farmers for their co-operation for the study.

\section{REFERENCES}

Ahmed, M.A.M., S. Ehui and Y. Assefa: Dairy Development in Ethiopia. EOTD Discussion Paper no.123. International Food Policy Research Institute, 73 pages, Washington DC, U.S.A., 2004.

American Public Health Association (APHA): Standard Method for the Examination of Dairy Products. $16^{\text {th }}$ ed., APHA, Washington, 1992, pp.: 213-223.
Asaminew,T. and Eyassu,S.: Microbial Quality of Raw Cow's Milk Collected from Farmers and Dairy Cooperatives in Bahir Dar Zuria and Mecha District, Ethiopia. Agric. Biol. J. N. Am., 2011, 2, 29-33.

Ethiopian Standard (ES): Unprocessed Whole/Raw Cow Milk Specification. $2^{\text {nd }}$ ed., 2009, ES 3460:2009.

Food and Agricultural Organization (FAO): The Lactoperoxidase System of Milk Preservation. Regional Lactoperoxidase Workshop in West Africa. Burkina Faso, 2001, 17-19.

Fikrineh N., Estefanos T. and Tatek W.: Microbial Quality and Chemical Composition of Raw Milk in the Mid-Rift Valley of Ethiopia. African Journal of Agricultural Research, 2012, 7, 4167-4170, Available online at http://www.academicjournals.org/AJAR, DOI: 10.5897/AJAR12.830, ISSN 1991-637X @2012 Academic Journals.

Fox N., Hunn A., and Mathers N.: Sampling and Sample Size Calculation, 41 pages, the NIHR RDS for the East Midlands / Yorkshire \& the Humber, 2007.

Francesconi, G.N.: Promoting Milk Quality of Cooperative Smallholders: Evidence from Ethiopia and Implications for Policy. In: Proceedings of Institutional Arrangements and Challenges in Market-Oriented Livestock Agriculture in Ethiopia, $14^{\text {th }}$ Annual Conference of the Ethiopian Society of Animal Production (ESAP) Held in Addis Ababa, Ethiopia, September 5-7, 2006 Part II: Technical Papers. ESAP, Addis Ababa, 2006, pp.: 32-39.

FRELICH, J. and ŠLACHTA, M.: Impact of Seasonal Grazing on Udder Health of Cows. Acta univ. agric. et silvic. Mendel. Brun., LIX, No. 1, 2011, pp.: 53-58.

Khan, M. T. G., Zinnah, M. A., Siddique M. P., Rashid M. H. A., Islam and, M. A. Choudhury and K. A.: Physical and Microbial Qualities of Raw Milk Collected from Bangladesh Agricultural University Dairy Farm and the Surrounding Villages, Bangladesh Agricultural University, Mymensingh-2202, Bangladesh, Bangl. J. Vet. Med., 2008, 6, 217-221.

Kurwijila, L.R.: Hygienic Milk Handling, Processing and Marketing: Reference Guide for Training and Certification of Small-Scale Milk Traders in Eastern Africa. ILRI (International Livestock Research Institute), Nairobi, Kenya, 2006, 11-26.

Mesfin, R. and Getachew, A.: Evaluation of Grazing Regimes on Milk Composition of Borana and Boran-Friesian Crossbred Dairy Cattle at Holetta Research Center, Ethiopia. Livestock Research for Rural Development, 2007, 19, Pages Article \#179. Retrieved September 18, 2012, from http://www.Irrd.org//lrd19/12/mesf19179.htm

O'connor, C.B.: Rural Dairy Technology, ILRI Training Manual 1, ILRI, Addis Ababa, Ethiopia, 1995, pp.: 82-83.

Oromia Planning and Economical Development Bureau (OPEDB): Physical and Socioeconomic Profile of 180 Districts of Oromiya Region, Addis Ababa, Ethiopia, 2000.

Ramesh C. Chandan: Manufacturing Yogurt and Fermented Milks, $6^{\text {th }}$ ed., Blackwell Publishing Ltd, Oxford, Uk, 2006, pp.: 7-40. 